\title{
INCREASING STUDENTS' VOCABULARY THROUG ENGAGE STUDY AND ACTIVE METHOD AT THE SECOND GRADE OF SMP 3 LEMBANG PINRANG REGENCY
}

\author{
St. Nurjannah Yunus Tekeng \\ Daharia \\ English Education Department of UIN Alauddin Makassar
}

\begin{abstract}
The objective of this research is to know whether the ESA method can increase the student vocabulary mastery at the second grade of SMP 3 Lembang Pinrang Regency. This study was focused on increasing students' vocabulary mastery through ESA method. The method of this research was classroom action research. It was conducted in two cycles. Each cycle consisted of four meetings. The data analysis techniques used qualitative and quantitative technique. The technique of data collected was observation, interview and test.

It was found that the student achievement and the performance from the first to the second cycle increased where in the first cycle the students' mean score only 64 percent which classified as "fair Good score" while in the second cycle the students' mean score is 82 percent which classified as "Good score". It can be said that, this research is successful because the students' score has achieved the research target. It is 75 percent as score of KKM in SMP 3 Lembang Pinrang Regency. In conclusion ESA method can increase the students' vocabulary mastery.
\end{abstract}

KEYWORDS: ESA method, students' vocabulary mastery

\section{A. INTRODUCTION}

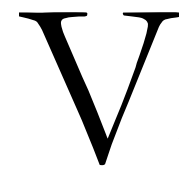

ocabulary is really important element of the language to be concerned in order to master the four language skills. Vocabularies are like fuels for car of language. Without enough vocabularies, the car of language cannot go as far as deal with our plan before. Learning English without mastery of vocabulary can make people trouble to write and they cannot answer some questions in spoken. By mastering a lot of vocabularies, student will be able to communicate each other, easier in doing exercise, and help them to express their ideas. Besides that,by mastering vocabulary, students can easily learn the language skills like reading, listening, speaking, and writing.

Even though vocabulary mastery is important in order to support the mastery in English skill, in fact many of English learners are often faced with the problem of vocabulary mastery. Based on a preliminary conducted at second grade of SMP 3 Lembang Rajang Pinrang Regency, it was found that; students' problem about mastering vocabulary due to several factors. First, the teaching learning process was less interesting as teacher gave monotonous method. Second, the students think that English is bored, scare and English is one of lesson subject is very difficult to master were unable to distinguish among noun and verb. Third the teacher often used translation method in teaching vocabulary that made 
students cannot remember the vocabularies in long period of time.

Based on the students' problem above the researcher applying ESA method as one of alternative to solve this problem. It is one of method form communicative learning method to increase students interest to study and it support by Harmer (2001:67) "Engage, Study, and Active method is element which are present in a language classroom to help student learn effectively and not make student bored and scare". In ESA method the teacher tries to increase the students' interest and engage their emotion. This might be through game, the use of picture, audio recording, or video sequence, drama story and amusing anecdote. The aim of this method is to arise the students' interest, curiosity and attention in lesson sequence. ESA method seems suggest student to build a motivation in listening.

There are some reasons why ESA method is chosen in increasing students' vocabulary mastery. First, Engage, Study, and Active method is a method can give motivate student to study. It gives student the chance to rehearse English, as they were doing in their daily life. Second, this method is an effective way for students and the teacher to assess whether the teaching and learning process is success or not.

Based on explain above researcher conclude that ESA method was an effective method that can be used in increasing students' vocabulary mastery. Therefore, by considering the previous description, the researcher had conducted a research entitled Increasing Students' Vocabulary Mastery Through Engage, Study, and Active method at the second grade of SMPN 3 Lembang Rajang Pinrang Regency.

\section{B. LITERATURE REVIEW}

Several studies had been conducted relating in teaching vocabularies: first Salam, (2008) in his thesis entitled Teaching English Vocabulary through ESA method (an Experimental Study at the second year students of SMPN 4 Tompobulu) concluded that teaching English vocabulary by using ESA method was a good way to increasing the students vocabulary. He found that 95.5 percent of the teaching English vocabulary to increase the students' vocabulary through ESA method learning strategy. He said that 95 percent were effectively way in learning vocabulary by using ESA method learning approach to increasing the students' vocabulary. Second, Harmi, (2008) in her Thesis entitled, increasing the Students' Vocabulary Achievement through ESA Method. She concluded that it was an effective way to increase the students' vocabulary because the students have bore and scare to study English because they are not interesting with their lesson, and, their grammatical knowledge was still low, and their ability arrange sentence was poor. It was because of they have insufficient vocabulary. She found that 90.2 percent of the students were increase in vocabulary through ESA method. She said that 97 percent used ESA method offer a good challenge for the students to learn or the subject were positively affected their interest. 
Based on the previous findings above, it can be concluded that, ESA method can increase students' vocabulary and ESA method have many media in learning process, therefore the researcher choose this method to increase students' vocabulary at the second grade of SMP 3 lembang Pinrang regency.

\section{ESA Method}

ESA method is a method to arise the students' interest to study. It support by Harmer (1998:237) states that ESA method is involves arousing learners' interest, curiosity and emotions towards the topic to attract attention and motivate them In addition to improve the students interesting, involvement and understanding on the new material. while according to Tomlinson (2013:238) state that "Engage, Study, Active is a method how to build students interest about a topic and the teacher identified as being problems in learning and the teacher should know to built and control that".

1. The ESA sequence lesson

According to Harmer in Edinburg (2001:54-56) the three element of ESA need to be present in lesson sequences, this does not mean that they should always occur in the same order. The order is bound to change the depending on what we want to achieve. Lesson planning is offering learning patterns for the students:

a. Engage- Study- Active are the teacher gets the class interested and engage, then they study something; then they try to active, it by putting in into production. Example:

- Engage is discussion about topic and what language to use

- Activate is role-play with teacher logging mistakes

- Study is error reflection/discourse analysis

- Activate is Role-play integrating study aspects

b. Engage- Active- Study- Active are the teacher gets the students engaged before asking them to do something like written task, a communicative game or a role-play. Based on what happen there, the student will then, after the activity has finished, study some aspect of language which they lacked or which they used incorrectly.

c. Engage is active- Active- Study- Active- Study- Engage- Active are which are different from the previous two procedures, may follow a variety of sequence. For example engage students are encouraged to active their knowledge before studying one and then another language element, and then returning to move activating tasks, after which the teacher re-engages them before doing some more study.

Engage, study, active are basic building blocks for successful language teaching and learning. By using them in different and varied sequences, teacher will be doing their best to promote their students' success since various theories and procedures.

2. The Teaching Process of ESA Method

According to Longman (1998:68) a complete lesson may be planned on the ESA model 
where the 50-60 minutes are divided into three different segments.

a. Engage is the point (activities) in a teaching sequence where Teacher tries to arouse Students' interest by involving their emotions. Some activities are: games, music, challenging discussions, stimulating pictures, dramatic stories, and anecdotes.

b. Study is the point (activities) in a teaching sequence where students are asked to focus in on language/information and how it is constructed. The range from macro to micro concentrations: Macro studying a transcript for spoken style. Micro studying a specific verb tense. It includes a variety of study styles: explanations, discovery through evidence, groups, whole-class, pairs, and individual. The main focus is the construction of language.

c. Activate is the point (activities) in a teaching sequence where students are meant to use the language as freely and communicatively as possible. The focus is not on construction, or practicing specific bits of language, it is for $S$ s to use all and any language appropriate for a given situation. Some activities are: role-plays, advertisement design, debate, discussions, describe and draw, story and poem writing/reading/telling, and group writing.

\section{Vocabulary}

Muhbubah, (2005:10 that Vocabulary is the concept and function word of language which are so thoroughly that become a part of child's understanding speaking, reading and writing. Vocabulary is the word having meaning when heard and seen even though it is not proceed by individual to communicate with other sometimes all the words recognize and understood by a particular person, although not necessary used by him. while In Oxford dictionary, (2008:495) asserts that vocabularies are: 1) all the words that a person knows or uses; 2) all the words in a language; 3) the words that people use when they are talking; 4) a list of words their meanings, especially in a book for learning a foreign language

\section{RESEARCHER METHOD}

This research used classroom action research method. It investigated the increasing students' vocabulary mastery through ESA method. According to Arikunto (2008) CAR for English Learning aims in developing a certain instructional strategy to solve practical instructional problems in English Classroom. It means that an Action Research which had been conducted in a classroom to increase the quality of learning teaching practices. CAR can be developed in the innovative instructional strategy that can help to enhance the students' success in learning English. One of expert state that Action Research is the systematic collection of information that is designed to bring out the social change.

Latief (2013) states that CAR is an effective media in improving the quality of English teachers' performance in instruction as well as students' achievement in learning English in Classrooms. CAR activities involve repeated cycles, each cycle consists of plan, 
action, observation, and reflection. According to Kemmis\&McTaggert (1988) the result of one cycle is used to determine the need for the cycle, until the problems get solved by the strategy.

There are many models of Classroom Action Research (CAR), they are:

1. Kurt Lewin Model

Kemmis in Wiriatmadja (2006) described this model start from identification of idea, reconnaissance, compiling the general planning, improve the first step, implementation of the first step, evaluation and make better the general planning. If the researcher need more research, they can do second implementation.

2. Kemmis and McTaggart

Kemmis and Taggart in Wiriatmadja (2006) described the model or the procedure of Classroom Action Research into four steps. They are; planning, acting, observing, and reflecting. The relations among them are called a cycle. It means that a cycle consists of planning, acting, observing, and reflecting.

3. Ebbutt Model

Hopkins in Wiriatmadja (2006) described this method start from: the first thinking of research, reconnaissance, the planning of entirety, Action, and Observation.

From three models above, the researcher used the spiral model by Kemmis and Taggart by considering that it was simple and easy to be understood.Kemmis and Taggart model is the development of Kurt Lewinmodel. It has the same basic activities. It could be seen as follows;

\section{Cycle I}

1. Planning

1) In this phase, the researcher prepared the material for the students.

2) The researcher made lesson plan based on the curriculum, and arrange material of lesson planning based on the ESA method in learning vocabulary.

3) The researcher made the observation paper to observe the condition of learning process.

4) The researcher arrange the test to know the increasing of the result study after they studied through ESA method.

2. Action

The action was carried out by using ESA method and the topic in each cycle was focused on vocabulary noun and verb.

1) First the researcher made the class interesting and the students were engaged to the real material, and then they tried to Activate by putting it into production.

2) Engage: the students were involved to look at a picture about part of body and they were order to ask some questions that they did not know about. 
3) Study: The researcher showed to students the picture of a particular part of body, the teacher introduced vocabulary and demonstrated the pronunciation of word and the researcher make sure the students can use correct grammar.

4) Activate: Students work in groups and did their task. They made a presentation in the class about the picture.

3. Observation

The observation was done during the learning process occurred contained. on the observation sheet there were many aspects that observed includes: the attendance of students, students who were active during the learning, students who were attention to the teacher during the learning process occurred, the student who asked about the subject matter did not understand, the student who asked for an explanation of a re-certain concepts that had discussed, students raised their hands when asked questions, students who cannot solve problems, and working on homework assignments.

4. Reflection

After collecting the data, the researcher evaluated the teaching learning process.Then, did reflection by seeing the result of the observation, whether the teaching learning process vocabulary through ESA method was success. Researcher and collaborator discuss about teaching and learning process that have done to find out the weakness and strength of ESA method how to improve the student weakness to the next meeting.

\section{FINDING AND DISCUSSION}

Result of students observation learning process in the first cycle. At the first time, the researcher introduced and explained the aim of this research to the students. the researcher gave the students' pre-test to know the students' vocabulary mastery. The test consists of 20 items fill in the blank questions. Based on the score of students pre-test, the researcher made planning to increase the students' ability in using ESA method

Table3. The result of the observation learning process in the first cycle

\begin{tabular}{|c|c|c|c|c|c|c|c|c|c|c|c|c|c|}
\hline \multirow[b]{3}{*}{ No } & \multirow{3}{*}{ Observation objects } & \multicolumn{12}{|c|}{ Score } \\
\hline & & \multicolumn{4}{|c|}{ Meeting 1} & \multicolumn{4}{|c|}{ Meeting 2} & \multicolumn{4}{|c|}{ Meeting 3} \\
\hline & & 4 & 3 & 2 & 1 & 4 & 3 & 2 & 1 & 4 & 3 & 2 & 1 \\
\hline 1. & $\begin{array}{l}\text { Thestudentinterest } \\
\text { tostudyduringthe } \\
\text { learning process }\end{array}$ & & & & $\sqrt{ }$ & & & $\sqrt{ }$ & & & & $\sqrt{ }$ & \\
\hline 2. & $\begin{array}{l}\text { Thestudentserious to } \\
\text { o the action }\end{array}$ & & & $\sqrt{ }$ & & & $\sqrt{ }$ & & & $\sqrt{ }$ & & & \\
\hline
\end{tabular}




\begin{tabular}{|l|l|l|l|l|l|l|l|l|l|l|l|l|l|}
\hline 3. & $\begin{array}{l}\text { Thestudentactivity } \\
\text { uring the learning }\end{array}$ & & & & $\sqrt{ }$ & & $\sqrt{ }$ & & & $\sqrt{ }$ & & & \\
\hline 4. & $\begin{array}{l}\text { Thestudent cooperated } \\
\text { in group }\end{array}$ & & & $\sqrt{ }$ & & & & $\sqrt{ }$ & & & & $\sqrt{ }$ & \\
\hline 5. & $\begin{array}{l}\text { Thewarmthofthe } \\
\text { learningenvironment }\end{array}$ & & & $\sqrt{ }$ & & & & $\sqrt{ }$ & & & $\sqrt{ }$ & & \\
\hline 6. & Students' participation & & & $\sqrt{ }$ & & & & $\sqrt{ }$ & & & $\sqrt{ }$ & \\
\hline
\end{tabular}

SuharsimiArikunto (2013)

Note: 4 = Very good, 3 = Good, 2 = Fair, $1=$ Poor

The table above showed the result of students' observation in the first cycle. The table consists of three columns. The first column provides information about indicator and the others columns provides information about the score of each meeting related to the students' responds.

The first indicatoris was the students' interest to study during the learning process. The table above indicated thatthe students' respond in the first meeting was poor because the applying new lesson method that was ESA, the second, and the third meeting the students' respond was good, because the students had adapted with the ESA method and the student were enjoy to study.

The second indicatoris was the seriousness of students in learning process. The table above showed that, the seriousness of students in the first meeting was poor because most of student did not give attention to the teachers' explanation and instruction while, in the second and third meeting, the students' respond was good, because the students did the task that the teacher gave.

The third indicator was the student activity during the learning process. The table showed that, in the first and the second meeting the students' respond was poor, because the student never askeda question or suggest an idea as long as during learning process. The third meeting the students' respond was very good, because the students were active and very enthusiastic in learning process.

The fourth indicator was the students cooperated in group.The table above showed that, the first and the second meeting, the students' respond was poor because the student did not cohesive to solve a problem that the teacher gave inthe discussion, the student were not active to give feedback with the other student and with the teacher .

The fifth indicator was the warmth of the learning environment, the table above showed that the first meeting, the student respond was poor, because most of students still shy and awkward with the new method, the second meeting the student respond was poor too because the student cannot do the task in group because they were not cohesive. The third meeting the students' respond was good because the student had been adapted to the method. 
The last indicator was students' participation in learning process, the table above showed that, the first until the third meeting, the students' partisipation was poor because most of students never suggest an idea and ask question during the learning process, the student was not cohesive to do the task that the teacher gave, and addition the student did not care teachers' explanation.

The table of observation above showed that, the students' responses were not maximal. There were still some indicators which must be improved because the students' responses were still low. Besides that, there were also some descriptors that did well, even though they still needed to be improved in the next cycle, so the researcher had to make planning again how to make student more active interest to study in the next cycle. The researcher gave new material or media that more interest to make student curiosity to study. And the result of student observation learning process in the second cycle

Table4. The result of the observation learning process in the second cycle No Observation objects Score

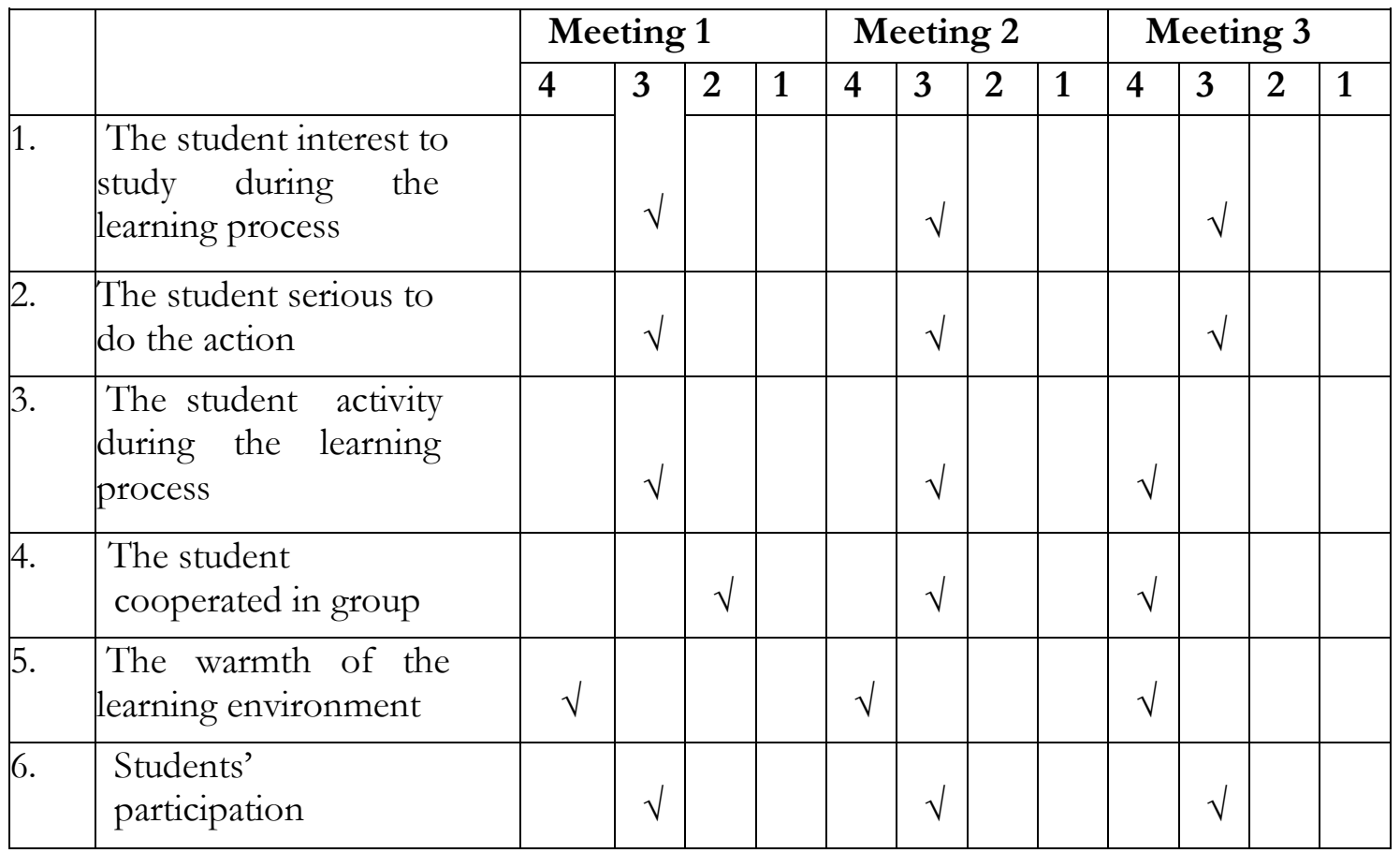

SuharsimiArikunto (2013)

Note: 4 = Very Good, 3 = Good, 2 = Fair, $1=$ Poor

The table above showed that,the result of students' observation in the second cycle. The indicators were same in the first cycle. The first column provides information aboutthe indicators and the others columns provides information about the score of each meeting related to the student responds.

The first indicator was the students' interestto study during the learning process. The table above showed that, the first until third meeting the students' respond was good because the students very enthusiastic to study in every meeting. It can see from the 
students' feedback and interact to reach good score by memorizing the new vocabularies that the teacher gave. the studentenjoy with the situation in the class, the student more interest with the new media that the teacher used at the time and the students' curiosity with the material was given.

The second indicator was the student serious to do the action. The table above showed that, the first until three meeting the students' respond was very good because the studentsdid the exercise based on the steps of the method, the student was not shy to express their ideas to the material and the student try to understand the instruction by using various learning aids, asking their students or their friends whenever they do not understand

The third indicator was the students' activity during the learning process. The table above showed that, the first meeting students' respond was good, because students very confidence to show their created in front of class. The second and third meeting the students' respond was good because thevery enthusiastic to do the task that the teacher gave.

The fourth indicator was the students' cooperated in group. The table above showed that, the first and second meeting the students' respond was poor because the student still had not cohesive to solve the problem that the teacher gave, but in the third meeting the student respond was good because the student can solve the problem without teacher guide again. Actively having discussion with the teachers and friends

The fifth indicator was the warmth of the learning environment. The table above showed that, the first until third meeting the students' respond was good because student very cohesive to do their task in every time, and did not awkward to do the task, the student enjoy in every time. The student was very welcome to the others students and also to the teacher.

The last indicator was the students' participant. The table above showed that, the first until third meeting the students respond was good because the students did not shy to express their ideas and gave suggest with the others students in discuss lesson, the student was active to give question and the student did not shy to interact with the teacher, and addition the student responsible to the task that the teacher gave.

Based on the table above, there were improvements of students' responds, and the table above indicated that most of indictors for each aspect had increased. The achievement test in the first and second cycle was conducted at SMP 3 Lembang Pinrang Regency. The results as follows; 
Table5.the mean score of students' vocabulary mastery.

\begin{tabular}{|l|l|l|l|l|l|l|}
\hline \multirow{2}{*}{ No } & \multirow{4}{*}{ Variable } & \multicolumn{2}{|l|}{ Cycle I } & \multicolumn{2}{l|}{ Cycle II } & \multirow{2}{*}{ Score } \\
\cline { 3 - 7 } & & & & Score & $\mathbf{\%}$ & \multirow{2}{*}{ Increasing } \\
\hline $\mathbf{1}$ & Noun & 6.0 & 60.00 & 8.0 & 80.00 & $20.00 \%$ \\
\hline $\mathbf{2}$ & Verb & 6.8 & 68.00 & 8.4 & 84.00 & $16.00 \%$ \\
\hline$\sum \mathbf{X}$ & 6.4 & 64.00 & 8.2 & 82.00 & $18.00 \%$ & $18.00 \%$ \\
\hline
\end{tabular}

The research findings from the table above showed that the students' vocabulary mastery was increased from the first cycle to the second cycle, where in first cycle the students' vocabulary was 64,00 percent, after evaluated in second cycle the students' vocabulary was 82,00 percent. In conclusion, ESA method can increase the students' vocabulary mastery at the second grade of SMP 3 Lembang Pinrang Regency.

\section{E. CONCLUTION}

Using Engage, Study, and Active (ESA) method in teaching can increase the students' vocabulary mastery in using noun and verb, after getting treatment of action research for 2 cycles it was found that the student score is 64 percent in the first cycle and 82 percent in the second cycle. It can be conclude that the use of ESA method in teaching and learning English process can increase the students' vocabulary mastery.

Some strengths of ESA method are; first, this method is appropriate in every level class because it has many media lessons in learning process such as video, music, picture, and amusing anecdote. Second, it can encourage because the teacher did not use monotone method in teaching, and the last, it is able to make students active in learning process because this method can stimulate the students to express their idea through some media that the teacher use in teaching process. In short ESA method was effective in increasing students' vocabulary mastery.

\section{REFERENCES}

Arikunto, Suharsini (2005).Procedure Penelitian: Suatu Pendekatan Praktek.Jakarta: PT. RinekaCipta.

British National Corpus, 2003.Oxford Advanced Learner's Dictionary. Oxford University of Chicago and London

Burns, Anne. (2010).Doing Action Research in English Language Teaching: A Guide for Practitioners. UK

Coady, J. M. 1986. Vocabulary Acquisitions: Mystery and Paradox. Anaheim, CA. International TESOl. 
St. Nurjannah Yunus Tekeng \& Daharia, Increasing Students' Vocabulary . . .

Firman. 2008. Increasing the Students' Vocabulary Achievement through STAN Method at the first year students of SMP Negeri 3 SinjaiBarat.Thesis Makassar Muhammadiyahuniversity.

Gay, L. R. 1981. Educational Research Competencies Analysis and Application, 3rd ed. Singapore: Macmillan Publishing Company.

Harmer, Jeremy. 2001. The Practice in English Teaching. New York: Longman. Harmer, Jeremy. 2007. How to Teach English. England: Longman.

Harmi. 2008. Increasing the Students' Vocabulary Achievement through ESA Method.Thesis in UNM Makassar.

Hirsh, D., \& Nation, P. 1992. What Vocabulary size is needed to read unsimplified texts for pleasure? Reading in a Foreign Language, 8 (2).

Hornby, A.S. (1995). Oxford Advance Learners' Dictionary. London: Oxford University Press

Jawariah. 2005. Building up Vocabulary mastery of the second year student of MTS pesantren An Nahdlah trough Translating Test. Thesis UIN Alauddin Makassar.

Logman. 2009. Magazine Style Theme Mag Essentials.

Article.http://www.pearsonlongman.com/teaching-tips/engage-studymotivate.html.

Larense, Diane and freeman, 2000.Techniques and Principles in language Teaching.oxford University of Chicago and London.

Mula, Suradi. 2000. Motivating the Students to Learn Vocabulary using Game Method. Thesis UIN Alauddin Makassar.

Mulbar, Agusman. 2002. Teaching Vocabulary through Poem to The Second Years Students of SMU Negeri II Makassar. Faculty of Teacher Training and Education.Thesis Makassar Muhammadiyahuniversity.

Mahbubah, Sitti. 2005. The Use of Word Attack in Developing Vocabulary Mastering to the Second Year Students of AliyabBuluLampang DDI MangkosoBarru. Thesis UIN Alauddin Makassar.

Nunan, David. 1995.Language Teaching Methodology.New york .PHOENIX ELT. Nurmala. 2008. Improving of the Students' Vocabulary Acbievement through the use of STAD Method.Thesis Makassar Muhammadiyahuniversity.

Published by Oxford University Press.2008.all right reserved.ELT Journal.http://scholar.google.co.id/scholar?q=learning+vocabulary+using+ES $\underline{A}+$ method \&hl $=\mathrm{id} \&$ as sdt $=0$ \&as vis $=1 \&$ oi $=$ scholart.

Salam. 2008. Thesis. Teaching English Vocabulary through ESA Method (an Experimental Study at the second year students of SMPN 4 Tompobulu).Thesis Makassar Muhammadiyah university.

Tuckman, R. W. 1999. Conducting Educational Research. 5th ed. America: Harcourt Brace and Company. 
Tweteng. 2009. Teaching English Forum-Topic/P']PP-Presentation-Practice- Production. Jurnal.http://www.teachingenglish.org.uk/forum-topic/ppp- presentation-practiceproduction

Ur, Penny.1996. A Course in Language Teaching Practice and Theory, Cambridge University press. Yapardi. 1995. Using Cards in Teaching English Teaching Vocabulary to Improving Achievement.Thesis sUIN AlauddinMakassar. 
